\title{
NOTES AND RECORDS
}

\section{VARIATIONS OF THE LEWIS GLACIER, MOUNT KENYA, 2004-2012}

\author{
Rainer Prinz, Lindsey Nicholson and Georg Kaser \\ With 3 figures, 3 tables and 1 supplement \\ Received 24. May 2012· Accepted 17. July 2012
}

\begin{abstract}
Summary: We present a new map of the Lewis Glacier, Mt Kenya ( $0^{\circ} 9^{\prime}$ S, 37 $\left.18^{\circ} \mathrm{E}\right)$, which was determined with a differential global positioning system survey and ice thickness measurements from ground penetrating radar that was carried out in 2010. The Lewis Glacier is among the best monitored tropical glaciers and this new map provides a continuation of glaciological monitoring at this site. Glacier area for 2010 is $0.107 \pm 0.001 \times 10^{6} \mathrm{~m}^{2}$ which is a $23 \%$ decrease since 2004 . The formerly adjoining Gregory Glacier no longer exists. Surface mass balance measurements for the years $2010 / 11$ and 2011/12 (-1.54 m water equivalent (w.e.) and -1.03 m w.e., respectively) are as negative as the minima measured between 1978 and 1996, and show a strong dependence on duration and depth of snow cover, which impact accumulation as mass input and ablation via the surface albedo.
\end{abstract}

Zusammenfassung: Wir stellen hier eine neue Karte des Lewis Gletschers am Mt. Kenya (09’ S, 37¹8’ E) vor, dessen Topographie mit differentiellem globalen Positionierungssystem und dessen Eisdicke mittels Bodenradar im Jahre 2010 aufgenommen wurde. Der Lewis Gletscher zählt zu den am besten untersuchten Gletschern der Tropen und diese Karte dient als Grundlage für weitere glaziologische Untersuchungen. Die Fläche des Gletschers betrug im Jahre $20100.107 \pm$ $0.001 \times 10^{6} \mathrm{~m}^{2}$ - um 23\% weniger als 2004. Der Gregory Gletscher, der ehemals mit dem Lewis Gletscher verbunden war, ist seitdem zur Gänze verschwunden. Die Massenbilanzen für die Jahre 2010/11 und 2011/12 (-1.54 m Wasseräquivalent (w.e.) beziehungsweise -1.03 m w.e.) sind ähnlich negativ wie die im Zeitraum 1978-1996 gemessenen Minima und sind stark von Dauer und Höhe der Schneedecke abhängig, die die Masse der Akkumulation bestimmt, aber auch die Ablation über die Albedo beeinflusst.

Keywords: Geosciences, Kenya, glacier mass balance, tropics

\section{Introduction}

Variations of low latitude glaciers are valuable indicators of environmental changes at tropical mid troposphere elevations (e.g., Hastenrath and Kruss 1992; Mölg et al. 2009; Vuille et al. 2008; WinKLER et al. 2010a, 2010b) where, due to lack of observational data, our knowledge of climate change is scarce and controversial (KARL et al. 2006; PAETH 2004; Trenberth et al. 2007). In particular, the Lewis Glacier $\left(0^{\circ} 9^{\prime} \mathrm{S}, 37^{\circ} 18^{\prime} \mathrm{E}\right)$ merits attention as it is among the best documented of all tropical glaciers, with almost 80 years of frequent observations of glacier length, area and volume changes (HASTENRATH 1984, 2005a; Prinz et al. 2011). Unfortunately, after 18 years (1978-1996) of continuous surface mass balance observations, measurements were halted and the last mapping of the glacier was accomplished in
2004. To preserve a degree of continuity of observations of the Lewis Glacier, we revived the monitoring program in 2009, as a part of a project involving a multi-scale approach to quantify glacier change and the climate-glacier relationship of the Lewis Glacier, Mt Kenya, triggered by the World Glacier Monitoring Service and funded by the Austrian Science Fund. Measuring current glacier extent is the first prerequisite for mass balance determination and assessment of glacier areal change over time.

To continue Stefan Hastenrath's reports of glacier variations on Mt Kenya to this journal (Caukwell and Hastenrath 1977; Hastenrath and CAukwell 1979, 1987; Hastenrath and Rostom 1990; Hastenrath 2005b; Hastenrath et al. 1989, 1995; Rostom and Hastenrath 1994, 1995, 2007), we present (i) a new map of the Lewis Glacier from our 2010 survey in conjunction with (ii) the surface 
mass balances for the years 2010/11 and 2011/12 (March-March respectively), which are discussed using data from an automatic weather station installed at the glacier.

\section{Mapping the Lewis Glacier in 2010}

\subsection{Field survey}

In two days (2 $2^{\text {nd }}$ and $3^{\text {rd }}$ of March 2010) the glacier outline and surface topography were surveyed using differential global positioning system (DGPS) receivers (Trimble Pathfinder ProXT and ProXH with external Zephyr antennas). To allow co-registration and, thus, comparison to previous maps, ground control points surrounding the Lewis Glacier, installed during an expedition to Mt Kenya in the International Geophysical Year (IGY) of 1957 (CHarnley 1959), were also surveyed (Tab. 1). These points define a local coordinate system that has been used in all subsequent mappings.

The base station was established at IGY ground control point L2 (see supplement map), and the ice extent was measured by collecting point locations every second while walking the rover instrument along the glacier margin. Where obstacles or cliffs forced the surveyor to deviate from the glacier margin, the survey path was offset from the true glacier margin by a set horizontal distance (maximum $2 \mathrm{~m}$ ) and the data were corrected manually for this offset after the differential post-processing step. The topography of the glacier surface was surveyed by traversing the glacier several times. After code and carrier phase post-processing, the ice surface and ice margin point locations were combined in a triangulated irregular network and interpolated to a digital elevation model (DEM) with $5 \mathrm{~m}$ grid point spacing.
The DGPS accuracy was $<30 \mathrm{~cm}$ for $58.8 \%(<1 \mathrm{~m}$ for $93.5 \%)$ horizontally and $<50 \mathrm{~cm}$ for $53.2 \%(<1 \mathrm{~m}$ for $86.9 \%$ ) vertically of a total of $>22000$ measured positions (Prinz et al. 2011 and associated supplementary material). Contours were derived from the DEM and generalized for cartographic reasons using the ArcGis 9.3 smooth line algorithm based on the Bezier interpolation. In addition, the supplement map shows ice thickness from ground penetrating radar measurements, described in detail by PRINZ et al. (2011). The map we present here is a reference surface to be used for on-going glaciological studies of the Lewis Glacier.

\subsection{Length, area and volume changes 2004-2010}

To compare the 2010 map to the previous map from 2004 (Rostom and Hastenrath 2007), two issues had to be considered. Firstly, it was necessary to bring both maps into the same coordinate system. Therefore, the 2004 map was transferred from its local coordinate system to the Universal Transverse Mercator coordinate system, using the DGPS positions of the IGY ground control points surrounding the Lewis Glacier as a reference. The root mean squared error of the georeferencing procedure is $<2 \mathrm{~m}$. Differences in altitude between DGPS and the IGY ground control points and height notations in the 2004 map are within $2 \mathrm{~m}$ on average (PRINZ et al. 2011 and associated supplementary material). Secondly, the ice divide between the Lewis and Gregory Glaciers (on the col between Point Lenana and Point Thomson) was defined from the 2004 map. Due to fog and snow cover during the 2010 survey, it was difficult to determine if the Gregory Glacier still existed. In March 2011 we observed that the Gregory Glacier has disappeared and only

Tab. 1: The IGY survey points in different coordinate systems. Heights are defined as meters above mean sea level

\begin{tabular}{|c|c|c|c|c|c|c|c|c|c|}
\hline \multirow{2}{*}{ IGY Point } & \multirow{2}{*}{ Code } & \multicolumn{3}{|c|}{ Hastenrath (2005) } & \multicolumn{3}{|c|}{ UTM (WGS84) Zone 37 M } & \multicolumn{2}{|c|}{ geographic coordinates } \\
\hline & & $\mathbf{X}$ & $\mathbf{Y}$ & Z & $\mathbf{X}$ & $\mathbf{Y}$ & Z & Latitude & Longitude \\
\hline L2 & L2 & 3210.6 & 1450.4 & 4797.2 & 312374.9 & 9982440.3 & 4796.4 & $0^{\circ} 9^{\prime} 31.675 ” \mathrm{~S}$ & $37^{\circ} 18^{\prime} 50.758^{\prime \prime} \mathrm{E}$ \\
\hline L3 & L3 & 2884.0 & 1791.8 & 4792.7 & 312048.3 & 9982783.8 & 4795.2 & $0^{\circ} 9^{\prime} 20.492$ " S & $37^{\circ} 18^{\prime} 40.196^{\prime \prime} \mathrm{E}$ \\
\hline Lenana & LE & 3622.1 & 1847.9 & 4985.0 & 312786.6 & 9982839.3 & 4987.7 & $0^{\circ} 99^{\prime} 18.686 " \mathrm{~S}$ & $37^{\circ} 19^{\prime} 04.071$ ” E \\
\hline S3 & S3 & 2745.5 & 1206.3 & 4600.6 & 311909.3 & 9982196.7 & 4605.0 & $0^{\circ} 9^{\prime} 39.605$ ” S & $37^{\circ} 18^{\prime} 35.700^{\prime \prime} \mathrm{E}$ \\
\hline \multicolumn{10}{|l|}{ Thomson } \\
\hline Cross & TC & 3165.5 & 2037.8 & 4958.1 & 312331.7 & 9983028.8 & 4959.7 & $0^{\circ} 9^{\prime} 12.517 ” \mathrm{~S}$ & $37^{\circ} 18^{\prime} 49.360^{\prime \prime} \mathrm{E}$ \\
\hline Top Hut & TH & 3177.5 & 1361.4 & 4809.4 & 312342.0 & 9982350.5 & 4809.9 & $0^{\circ} 9^{\prime} 34.598$ "' S & $37^{\circ} 18^{\prime} 49.694^{\prime \prime} \mathrm{E}$ \\
\hline accuracy & & $\pm 0.5 \mathrm{~m}$ & $\pm 0.5 \mathrm{~m}$ & $\pm 0.3 \mathrm{~m}$ & $\pm 0.1 \mathrm{~m}$ & $\pm 0.1 \mathrm{~m}$ & $\pm 0.3 \mathrm{~m}$ & $\pm 0.003^{\prime \prime}$ & $\pm 0.003 ”$ \\
\hline & & \multicolumn{3}{|c|}{ CHARNLEY (1959) } & \multicolumn{5}{|c|}{ PRINZ et al. (2011) } \\
\hline
\end{tabular}


debris covered ice remnants of unknown thickness remain (Prinz et al. 2011). However, a small portion $\left(2 \times 10^{3} \mathrm{~m}^{2}\right)$ of the Lewis Glacier still points towards the former flow direction of the Gregory Glacier. For mass balance studies of the Lewis Glacier, this portion is considered part of the total surface area $\left(0.107 \pm 0.001 \times 10^{6} \mathrm{~m}^{2}\right.$; although its contribution to the area is within the range of the total area accuracy), but for consistency with how the glacier was delineated in previous mappings, it is subtracted from the reported total surface area $\left(0.105 \pm 0.001 \times 10^{6}\right.$ $\mathrm{m}^{2}$ ) and glacier volume.

Table 2 lists data of glacier length, area and volume of 2004 and 2010. Over these six years, the glacier terminus retreated $79 \mathrm{~m}$ upslope. The total central flowline length change is greater than the terminus retreat because of loss of ice area in the uppermost part of the glacier.

\section{Surface mass balance 2010-2012}

The surface mass balance was measured with the direct glaciological approach using a floating date time system (Cogley et al. 2011; HoinKes 1970), although the sampling dates were within 5 days of each other. Ablation was measured using surface height change against bamboo ablation stakes drilled into the ice with a mechanical auger, and accumulation was determined from snow depth measurements made by probing the snow layer in conjunction with density measurements from snow pits. To identify specific patterns of surface height change over the glacier area, 26 ablation stakes were distributed over the surface of the Lewis Glacier on the $25^{\text {th }}$ of September, 2009. This is a fairly high coverage of 260 stakes $/ \mathrm{km}^{2}$ and once areas of similar patterns are discovered, the number of ablation stakes can be reduced accordingly. On the upper part of the glacier, ablation stake density is less because blocks falling from slopes of Point Lenana pose a hazard to the stakes and to measurement of them. Each bamboo stake measures 2-4 m in length and was read and usually replaced twice a year. Accumulation measurements were sparse since there is no pronounced accumulation season and ablation occurs year round. The glacier was snow covered three times during our field visits (March 2010: 5-20 cm, September 2010: 15-50 cm and September 2011: $15-50 \mathrm{~cm}$ ) with a bulk snow density of $430 \mathrm{~kg} / \mathrm{m}^{3}$, averaged over all our snow density measurements. Ice density was assumed to be $900 \mathrm{~kg} / \mathrm{m}^{3}$.
Tab.2: Changes of length, area and volume of the Lewis Glacier 2004-2010 (PrinZ et al. 2011)

\begin{tabular}{cccccc}
\hline & Length* & \multicolumn{2}{c}{ Area } & \multicolumn{2}{c}{ Volume } \\
\hline & $\mathrm{m}$ & $10^{6} \mathrm{~m}^{2}$ & $\pm 10^{6} \mathrm{~m}^{2}$ & $10^{6} \mathrm{~m}^{3}$ & $\pm 10^{6} \mathrm{~m}^{3}$ \\
$\mathbf{2 0 0 4}$ & 746 & 0.136 & 0.007 & 2.37 & 0.49 \\
$\mathbf{2 0 1 0}$ & 613 & 0.105 & 0.001 & 1.90 & 0.30 \\
Difference & -133 & -0.031 & 0.007 & -0.47 & 0.57 \\
\hline
\end{tabular}

* Length of the approximated central flow line; position of the glacier front: $-79 \mathrm{~m}$

For consistency with Hastenrath (2005a), the mass balance year on Mt Kenya begins on the $1^{\text {st }}$ of March and can be subdivided in two wet seasons (March-May, MAM and October-December, OND), separated by two dry seasons (June-September, JJAS and January-February, JF). However, as observed in meteorological measurements from the glacier surface, wet seasons may fail and dry seasons may contribute significantly to the total annual precipitation.

The annual surface mass balances 2010-2012 of the Lewis Glacier are shown in table 3. Areas of same volume change were manually interpolated between ablation stake records, digitized and calculated as area-weighted averages for $50 \mathrm{~m}$ altitudinal zones. Most (least) negative values were recorded at the glacier tongue (at the central upper part). In both years, the glacier experienced mass loss over the entire surface, thus the equilibrium line altitudes are undefined (Fig. 1 and Fig. 2). This was also the case for ten years of the historical record from 1978-1996 (HASTENRATH 2005a), indicating that the hypothetical equilibrium line altitude has frequently been higher than the upper limit of the glacier over recent decades.

\section{Discussion}

Spatial patterns of the surface mass balance (Fig. 1) are generally controlled by local geometry and its interaction with the radiative energy balance of the glacier surface (Kruss and Hastenrath 1987). High mass loss that was observed in the 2011/12 mass balance year on the northernmost edge of the glacier (the former part of Gregory Glacier; on the col between Point Lenana and Point Thomson), where the north-easterly aspect favours ablation in the usually clear sky morning hours, substantiates this finding. However two features, in which other meteorological influences strongly modulate the radiative energy 
Tab.3: The surface mass balances of the Lewis Glacier 2010-2012 for $50 \mathrm{~m}$ altitudinal zones

\begin{tabular}{|c|c|c|c|c|c|}
\hline \multirow{2}{*}{$\begin{array}{c}\text { Altitudinal } \\
\text { Zone }\end{array}$} & \multirow{2}{*}{$\begin{array}{c}\text { Area } \\
{\left[10^{3} \mathrm{~m}^{2}\right]}\end{array}$} & \multicolumn{2}{|c|}{ Volume Change $\left[10^{3} \mathrm{~m}^{3}\right]$} & \multicolumn{2}{|c|}{ Surface Mass Balance [m w.e.] } \\
\hline & & 2010/11 & $2011 / 12$ & $2010 / 11$ & $2011 / 12$ \\
\hline 4675 & 9,1 & $-19,6$ & $-18,9$ & $-2,15$ & $-2,07$ \\
\hline 4725 & 21,8 & $-42,6$ & $-38,3$ & $-1,95$ & $-1,75$ \\
\hline 4775 & 19,7 & $-32,7$ & $-19,9$ & $-1,66$ & $-1,01$ \\
\hline 4825 & 43,2 & $-54,2$ & $-25,7$ & $-1,26$ & $-0,59$ \\
\hline 4875 & 13,7 & $-16,8$ & $-7,9$ & $-1,23$ & $-0,58$ \\
\hline total & 107,5 & $-165,9$ & $-110,6$ & $-1,54$ & $-1,03$ \\
\hline
\end{tabular}

balance, were observed: (i) Large dissimilarities in measured surface mass balance over short distances between neighbouring ablation stakes indicate large differences in surface conditions on a very small scale without year-to-year consistency, complicating the spatial interpolation of surface mass balance patterns. (ii) Contrasting mass loss patterns on the lower part of the glacier in the two years of observation cannot be explained qualitatively and were not reported in the historical surface mass balance record (HASTENRATH 2005a), perhaps due to a lower ablation stake density. These issues must be further investigated and quantified using an energy balance approach.

The elevation dependence of the surface mass balance is primarily a result of albedo feedback. Snow accumulation varies little over the glacier surface and measured accumulation gradients show no systematic variation with elevation. However, field observations of ascending snowlines after relatively uniform snowfall events indicate that slightly higher ablation rates towards the terminus of the glacier result in more rapid and more frequent removal of snow cover from the ice surface which then, as it has a lower albedo than the upper zones that are still snow covered, is subject to further enhanced ablation rates. Although ablation often removes the snow from the entire glacier surface, exposing ice at all elevations, frequent snowfall events would result in a relatively thicker snowpack towards the top of the glacier as compared to the lower reaches, where snow is removed at a faster rate.

To allow a climatic interpretation of the surface height change at a higher temporal resolution, an automatic weather station was set up on the glacier at $4828 \mathrm{~m}$ and operated from September 2009 - March 2012. Amongst other meteorological variables, this station recorded half-hourly means of surface height, albedo and air temperature from measurements taken every minute. Figure 3 shows large albedo variations in MAM 2010 indicating rapid melting of frequent shallow snow covers. Minimum albedo coincides with maximum air temperature, suggesting a water-saturated, melting ice surface until July. The sparse accumulation in OND was quickly removed in the following JF 2011 dry season, exposing bare ice to ablation processes. The mass balance year 2011/12 started with a short period of very low albedo followed by very light snowfalls, immediately increasing the albedo. Although no major accumulation event was recorded during the MAM 2011 wet season, which almost completely failed over East Africa (LYON and DeWITT 2012), the albedo remained high throughout March and April. This contrast in albedo conditions between MAM 2010 and MAM 2011 is likely related to how the potential melting rate is influenced by air temperature, which showed a marked thermal optimum in MAM 2010 that was absent the following year. Frequent abundant snowfall events from July to December 2011 partly compensated the MAM lack of accumulation. However, as in 2011, no accumulation was preserved during the JF 2012 dry season, resulting in negative mass balances over the entire glacier surface.

\section{Conclusion and outlook}

Glaciological monitoring of the Lewis Glacier, one of the few tropical reference glaciers, has been continued by surveying the glacier topography and measuring the annual surface mass balance. The 2010 survey updates records of length, area and volume changes in the same frame of reference as historical surveys, and thus forms the basis for continuing glaciological work on Mt Kenya. Glacier mass change at Lewis Glacier retains its negative trend as observed in both direct and geodetic measurements and the formerly connected Gregory Glacier has now disappeared entirely. 

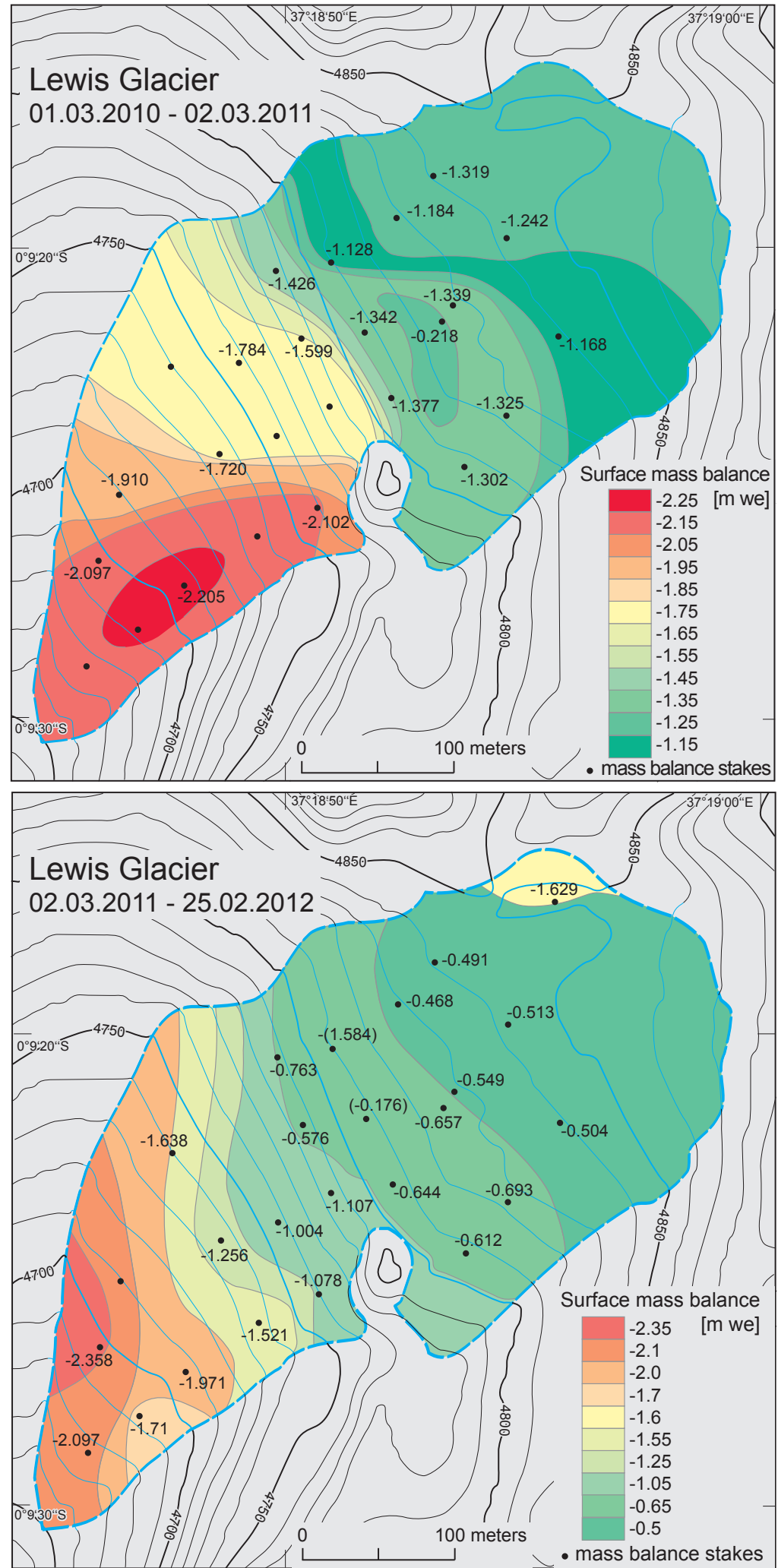

Fig. 1: Areal distribution of surface mass balances for the years 2010/11 (top) and 2011/12 (bottom). Note the different colour scaling. Values in brackets are questionable and not used for areal interpolation. Stake positions without numbers indicate missing data 


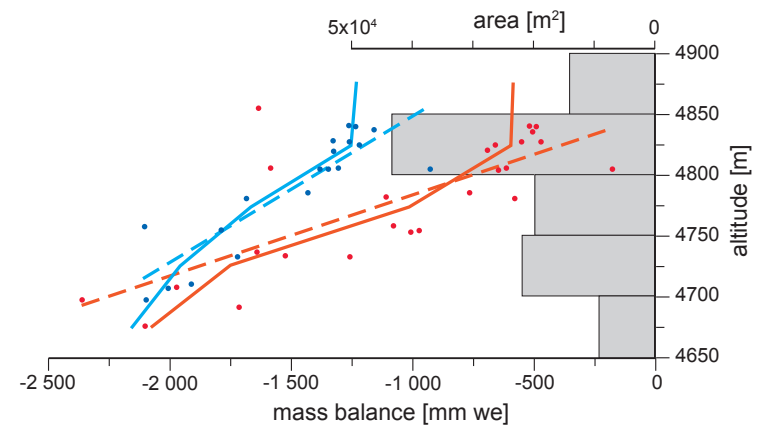

Fig. 2: Solid lines show the vertical surface mass balance profiles for the years 2010/11 (blue) and 2011/12 (red). Points depict the measured surface mass balance at individual ablation stakes, which are linearly interpolated by the dashed lines. Grey bars (reversed x-axis on top) indicate the area altitude distribution of the Lewis Glacier

The inter-annual variability in the surface mass balance of the Lewis Glacier is large and meteorological data measured above the glacier surface indicate that a combination of persistently higher air temperatures, in conjunction with little snow accumulation over the course of the year resulted in a more negative surface mass balance in 2010/11 than in 2011/12, during which daily mean air temperature remained predominantly below $0{ }^{\circ} \mathrm{C}$ and more snow was accumulated over a longer period. Hence, the stronger gradients of (i) ablation (0.8 compared to $1.5 \mathrm{~m}$ w.e./100 $\mathrm{m}$ for $2010 / 11$ and $2011 / 12$, respectively) and (ii) the vertical surface mass balance profile (Fig. 2) mainly resulted from more frequent or more persistent snow cover on the upper part of the glacier in the 2011/12 mass balance year. This sensitivity of the vertical surface mass balance profile of glaciers in the humid inner tropics to changes in net shortwave radiation (controlled by the surface albedo) and air temperature is conceptually explained in a modelling approach by KASER (2001).

The impact and relative importance of variations of air temperature, precipitation and other atmospheric drivers on the glacier surface mass and energy balance will be investigated more fully in forthcoming mass and energy balance modelling work.
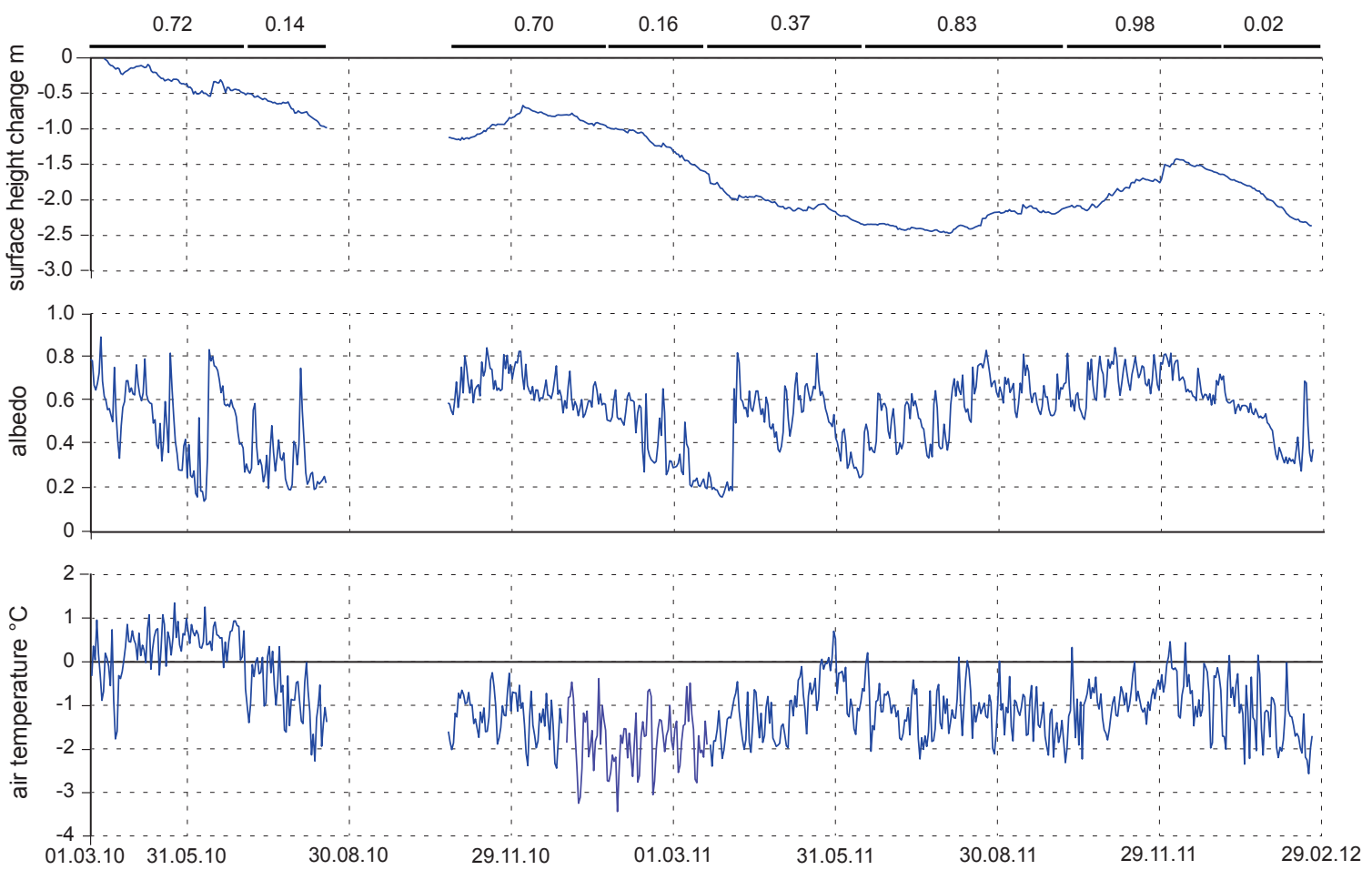

Fig. 3: Daily means of (top) surface height change measured from a Campbell SR50 sonic ranger; values above give seasonal sums of daily snowfall in meter; (middle) albedo as a ratio of daily totals of reflected solar radiation to daily amounts of global radiation (OERLEMANS and KNAP 1998) from a Kipp\&Zonen CNR4 net radiometer and (bottom) air temperature from an unventilated Vaisala HMP45 probe at the automatic weather station at Lewis Glacier at $4828 \mathrm{~m}$ from 01.03 .2010 to 23.02.2012 (data gap from 20.07.-27.09.2010) 


\section{Acknowledgements}

This study was funded by the Austrian Science Fund (FWF grant P21288-N21). We thank the assistants during the high altitude field campaigns: A. Fischer, S. Galos, M. Kaser and M. Schultz as well as the Mount Kenya Guides and Porters Safari Club who have supported all our expeditions to the mountain. We very much appreciate the local support of the National Council of Science and Technology (NCST/5/002/R/692), the Kenya Wildlife Service (S. Gitau), the Kenya Meteorological Department, and UNEP/DEWA (C. Lambrechts).

\section{References}

Caukwell, R. A. and Hastenrath, S. (1977): A new map of Lewis Glacier, Mount Kenya. In: Erdkunde 31 (2), 85-87. DOI:10.3112/erdkunde.1977.02.02

Charnley, F. E. (1959): Some observations on the glaciers of Mount Kenya. In: Journal of Glaciology, 3 (26), 483-492.

Cogley, J. G.; Hock, R.; Rasmussen, L. A.; Arendt, A. A.; Bauder, A.; Braithwatte, R. J.; Jansson, P.; Kaser, G.; Möller, M.; Nicholson, L. and Zemp, M. (2011): Glossary of mass balance and related terms. UNESCO-IHP. Paris.

Hastenrath, S. (1984): The glaciers of equatorial East Africa. Dordrecht, Boston, Lancaster.

- (2005a): Glaciological studies on Mount Kenya. Madison.

- (2005b): The glaciers of Mount Kenya 1899-2004. In: Erdkunde 59 (2), 120-125. DOI: 10.3112/erdkunde.2005.02.03

Hastenrath, S. and Caukwell, R. A. (1979): Variations of Lewis Glacier, Mount Kenya, 1974-78. In: Erdkunde 33 (4), 292-297. DOI: 10.3112 /erdkunde.1979.04.06

- (1987): Variations of Lewis Glacier, Mount Kenya, 198286. In: Erdkunde 41 (1), 37-41. DOI: 10.3112/erdkunde.1987.01.04

Hastenrath, S. and Kruss, P. D. (1992): Greenhouse indicators in Kenya. In: Nature 335, 503-504. DOI: $10.1038 / 355503 \mathrm{~b} 0$

Hastenrath, S. and Rostom, R. S. (1990): Variations of the Lewis and Gregory Glaciers, Mount Kenya, 1978-8690. In: Erdkunde 44 (4), 313-317. DOI: 10.3112/erdkunde.1990.04.06

Hastenrath, S.; Rostom, R. S. and Caukwell, R. A. (1989): Variations of Mount Kenya's glaciers 1963-87 In: Erdkunde 43 (3), 202-210. DOI: 10.3112/erdkunde.1989.03.05

Hastenrath, S.; Rostom, R. S. and Hime, W. F. (1995): Variations of the Lewis and Gregory Glaciers, Mount Kenya, 1990-1993. In: Erdkunde 49 (1), 60-62. DOI: 10.3112/ erdkunde.1995.01.06
Hoinkes, H. (1970): Methoden und Möglichkeiten von Massenhaushaltsstudien auf Gletschern. Ergebnisse der Messreihe Hintereisferner (Ötztaler Alpen) 1953-1968. In: Zeitschrift für Gletscherkunde und Glazialgeologie 6, 37-90.

Karl, T. R.; Hassol, S. J.; Miller, C. D. and Murray, W. L. (2006): Temperature trends in the lower atmosphere: steps for understanding and reconciling differences. Washington, DC.

Kaser, G. (2001): Glacier-climate interaction at low latitudes. In: Journal of Glaciology 47 (157), 195-204. DOI: $10.3189 / 172756501781832296$

Kruss, P. D. and Hastenrath, S. (1987): The role of radiation geometry in the climate response of Mount Kenya's glaciers. Part I: Horizontal reference surfaces. In: International Journal of Climatology, 7 (5), 493-505. DOI: 10.1002/joc.3370070505

Lyon, B. and DeWitT, D. G. (2012): A recent and abrupt decline in the East African long rains. In: Geophysical Research Letters 39 (2), 1-5. DOI: 10.1029/2011GL050337

Mölg, T.; Cullen, N. J.; Hardy, D. R.; Winkler, M. and Kaser, G. (2009): Quantifying climate change in the tropical midtroposphere over East Africa from glacier shrinkage on Kilimanjaro. In: Journal of Climate 22 (15), 4162-4181. DOI: 10.1175/2009JCLI2954.1

Oerlemans, J. and Knap, W. H. (1998): A one-year record of global radiation and albedo in the ablation zone of the Morteratschgletscher, Switzerland. In: Journal of Glaciology 44 (147), 231-238.

Paeth, H. (2004): Key factors in African climate change evaluated by a regional climate model. In: Erdkunde 58 (4), 290-315. DOI: 10.3112/erdkunde.2004.04.02

Prinz, R.; Fischer, A.; Nicholson, L. and Kaser, G. (2011): Seventy-six years of mean mass balance rates derived from recent and re-evaluated ice volume measurements on tropical Lewis Glacier, Mount Kenya. In: Geophysical Research Letters 38 (20), L20502. DOI: 10.1029/2011GL049208

Rostom, R. S. and Hastenrath, S. (1994): Variations of Mount Kenya's glaciers 1987-1993. In: Erdkunde 48 (3), 174-180. DOI: 10.3112/erdkunde.1994.03.02

- (1995): Mapping the glaciers of Mount Kenya in 1947. In: Erdkunde 49 (3), 244-249. DOI: 10.3112/erdkunde.1995.03.06

- (2007): Variations of Mount Kenya's glaciers 1993-2004. In: Erdkunde 61 (3), 277-283. DOI: 10.3112/erdkunde.2007.03.05

Trenberth, K. E.; Jones, P. D.; Ambenje, P.; Bojariu, R.; EAsterling, D.; Klein Tank, A.; Parker, D.; Rahimzadeh, F.; Renwick, J. A.; Rusticucci, M.; Soden, B. and Zhai, P. (2007): Observations: surface and atmospheric climate change. In: Solomon, S.; Qin, D.; Manning, M.; Chen, Z.; Marquis, M.; Averyt, K. B.; Tignor, M. and Miller, 
H. L. (eds.): Climatic change 2007: the physical science basis. Contribution of Working Group I to the Fourth Assessment Report of the Intergovernmental Panel on Climate Change. Cambridge UK, New York, NY.

Vuille, M.; Kaser, G. and Juen, I. (2008): Glacier mass balance variability in the Cordillera Blanca, Peru and its relationship with climate and the large-scale circulation. In: Global and Planetary Change 62 (1-2), 14-28. DOI: 10.1016/j.gloplacha.2007.11.003

Winkler, M.; Kaser, G.; Cullen, N. J.; Mölg, T.; Hardy, D. R. and Pfeffer, W. T. (2010a): Land-based marginal ice cliffs: focus on Kilimanjaro. In: Erdkunde 64 (2), 179-193. DOI: 10.3112/erdkunde.2010.02.05

Winkler, S.; Chinn, T.; Gärtner-Roer, I.; Nussbaumer, S. U.; Zemp, M. and ZumbÜHL, H. J. (2010b): An introduction to mountain glaciers as climate indicators with spatial and temporal diversity. In: Erdkunde 64 (2), 97-118.

DOI: 10.3112 /erdkunde.2010.02.01

Authors

Mag. Rainer Prinz Dr. Lindsey Nicholson Prof. Dr. Georg Kaser Institute of Meteorology and Geophysics Centre of Climate and Cryosphere University of Innsbruck

Innrain 52 6020 Innsbruck Austria rainer.prinz@uibk.ac.at lindsey.nicholson@uibk.ac.at georg.kaser@uibk.ac.at 


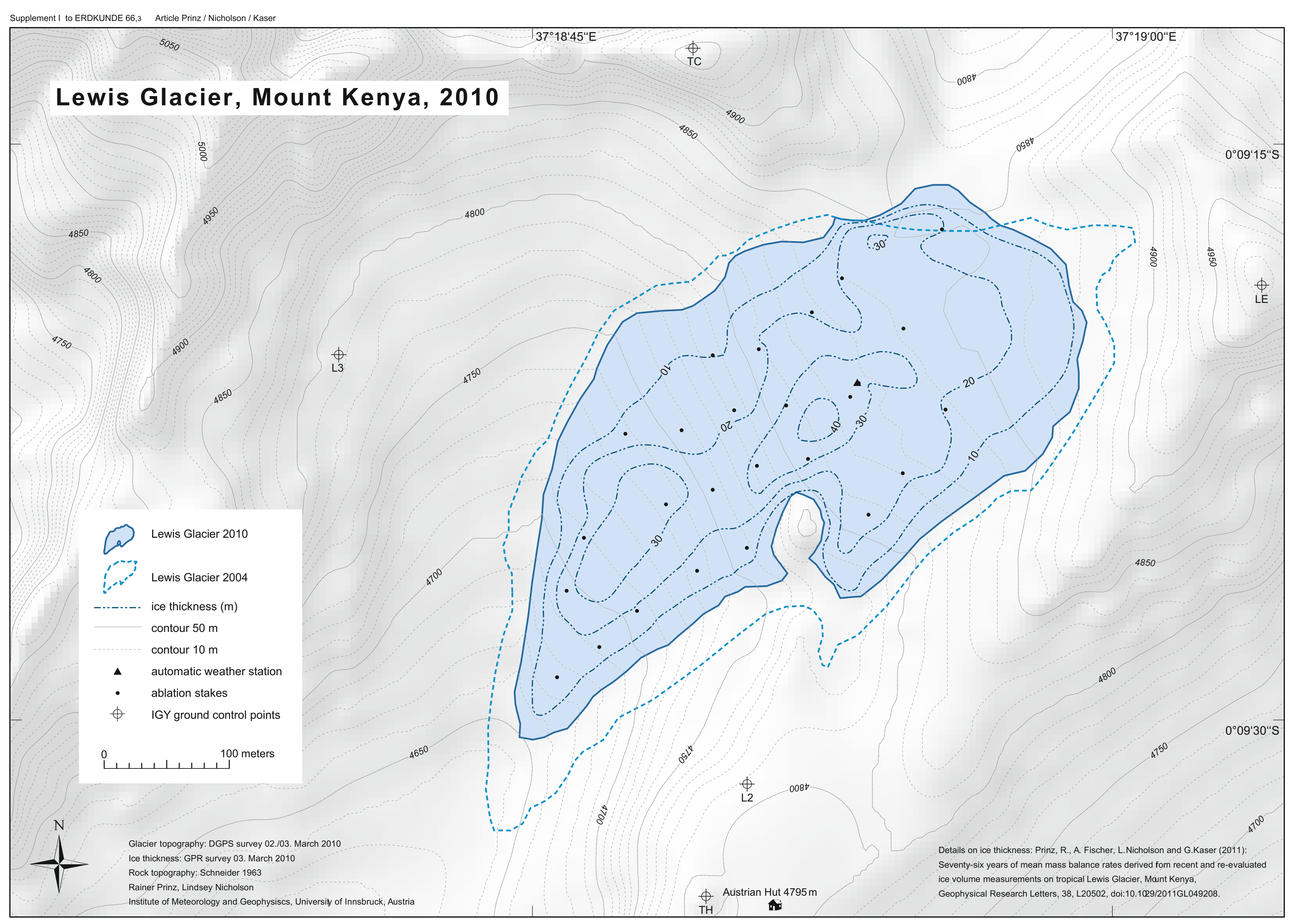

